\title{
Emergence of plasmid-mediated colistin resistance (MCR-1) among Escherichia coli isolated from South African patients
}

\begin{abstract}
J Coetzee, C Corcoran, E Prentice, M Moodley, M Mendelson, L Poirel, P Nordmann, A J Brink
Jennifer Coetzee, Craig Corcoran and Elizabeth Prentice are all specialists in the Departments of Clinical Microbiology and Molecular Sciences at the Ampath Reference Laboratory, Centurion, Pretoria, South Africa. Mischka Moodley is a clinical microbiologist at the Ampath National Laboratory Services, Cape Town, South Africa. Marc Mendelson is an infectious diseases specialist and Head of Infectious Diseases and HIV Medicine at the Department of Medicine, Faculty of Health Sciences, University of Cape Town, South Africa. Laurent Poirel and Patricia Nordmann are microbiologists in the Emerging Antibiotic Resistance Unit, Department of Medical and Molecular Microbiology, Department of Medicine, Faculty of Science, University of Fribourg, Switzerland. Adrian Brink is a clinical microbiologist at Ampath National Laboratory Services, Milpark Hospital, Johannesburg.
\end{abstract}

Corresponding author: J Coetzee (coetzeej@ampath.co.za)

The polymyxin antibiotic colistin is an antibiotic of last resort for the treatment of extensively drug-resistant Gram-negative bacteria, including carbapenemase-producing Enterobacteriaceae. The State of the World's Antibiotics report in 2015 highlighted South Africa (SA)'s increasing incidence of these 'superbugs' (3.2\% of Klebsiella pneumoniae reported from SA were carbapenemase producers), and in doing so, underscored SA's increasing reliance on colistin as a last line of defence. Colistin resistance effectively renders such increasingly common infections untreatable.

S Afr Med J 2016;106(5):449-450. DOI:10.7196/SAMJ.2016.v106i5.10710

\section{Current global concerins}

In the 2015 State of the World's Antibiotics ${ }^{[1]}$ report, an increasing incidence of extensively drug-resistant Gram-negative bacteria was highlighted for South Africa (SA), underscoring SA's increasing reliance on colistin as a last line of defence. Although colistin resistance was first reported in the Czech Republic in 1999 and was subsequently only reported sporadically, recent reports of increasing colistin resistance among clinical isolates, including from SA, are cause for alarm..$^{[2,3]}$ Of particular concern is the emergence of colistin resistance among commonly encountered Enterobacteriaceae such as Klebsiella pneumoniae. Up to now, the mechanism of colistin resistance in SA isolates was due to changes in genes associated with complex alterations in the bacterial regulatory systems. ${ }^{[4]}$ These genes were not readily transferrable between species.

Recent routine surveillance of antibiotic resistance in commensal Escherichia coli from food animals in China documented a major increase of colistin resistance due to a highly mobile, transferrable, plasmid-mediated colistin-resistance gene designated $m c r-1 .{ }^{[5]}$ They observed $m c r-1$ in E. coli isolates collected from $15 \%$ (78/523) of raw retail meat samples (chicken and pork) and $21 \%$ (166/804) of animals (pigs) during 2011 - 2014. Of note, 1\% (16/1 322) of clinical isolates from infected, hospitalised Chinese patients harboured $m c r-1$. The authors demonstrated transfer of $m c r-1$ between $E$. coli strains, including strains with known epidemic potential, such as ST131. Furthermore, the plasmid could be passed to K. pneumoniae and even Pseudomonas aeruginosa strains.

Globally, the dissemination of $m c r-1$ among E. coli strains from feed animals and asymptomatic humans has now been reported from at least 17 countries. Recently, Dutch travellers to Asia (China, Thailand, Vietnam, Cambodia and Laos), North Africa
(Tunisia) and South America (Peru, Bolivia and Colombia) were reported, after their travels, to have gastrointestinal colonisation with $m c r-1$-containing E. coli. ${ }^{[6]} \mathrm{mcr}-1$ has also been detected among Salmonella spp. collected in 2012 - 2013 from the French agricultural food sector and has been confirmed in Salmonella enterica serotype typhimurium cultured from food samples in Portugal. In addition, the $m c r-1$ gene has been identified in clinical isolates of K. pneumoniae and in association with carbapenemase genes. ${ }^{[7]}$

\section{Current situation in SA}

A countrywide surveillance programme of poultry operations revealed that colistin resistance in E. coli strains increased substantially in 2015, predominantly in the second half of the year. ${ }^{[8]}$ It was surmised that this sudden increase was likely due to the selection of mcr-1-containing strains where colistin was being used. Subsequent analysis detected $m c r-1$ in 19/24 (79\%) colistin-resistant cultures from the last quarter of 2015.

Of critical importance, $m c r-1$ has now been detected in clinical isolates of colistin-resistant $E$. coli from hospitalised $(n=3)$ and outpatient-based $(n=6)$ patients in SA. This has been confirmed by a specialised antibiotic resistance unit in Switzerland that performed confirmatory molecular studies including plasmid characterisation (submitted for publication). As depicted in Table 1, mcr-1-positive, colistin-resistant E. coli was cultured from patients in two SA provinces. Except for one patient with an abscess, all the community-acquired cases presented to primary care with urinary tract infections. None was previously exposed to colistin. $m c r-1$ leads to raised colistin minimum inhibitory concentrations of $4-8 \mathrm{mg} / \mathrm{L}$. Four of the isolates coproduced an extended-spectrum $\beta$-lactamase (data not shown). 
Table 1. Demographics of clinical isolates of $m c r-1$-containing $E$. coli

\begin{tabular}{|c|c|c|c|c|c|c|c|c|c|}
\hline & $\begin{array}{l}\text { Age (years), } \\
\text { sex }\end{array}$ & Source & $\begin{array}{l}\text { Admission } \\
\text { date }\end{array}$ & Culture date & $\begin{array}{l}\text { Colistin } \\
\operatorname{MIC}(\mathrm{mg} / \mathrm{L})\end{array}$ & $\begin{array}{l}\text { Clinical } \\
\text { diagnosis }\end{array}$ & $\begin{array}{l}\text { Prior } \\
\text { colistin }\end{array}$ & City & $\begin{array}{l}\text { Additional } \\
\text { comments }\end{array}$ \\
\hline 1 & $54, \mathrm{M}$ & Blood & NR & 23 March 2014 & 4 & $\begin{array}{l}\text { Stem cell } \\
\text { transplant }\end{array}$ & No & Pretoria & $\begin{array}{l}\text { Prior carbapenem } \\
\text { and fluoroquinolone } \\
\text { treatment }\end{array}$ \\
\hline 2 & $60, \mathrm{~F}$ & $\begin{array}{l}\text { Wound } \\
\text { (bedsore) }\end{array}$ & $\begin{array}{l}9 \text { February } \\
2015 \text { (ICU) }\end{array}$ & 12 March 2015 & 4 & $\begin{array}{l}\text { AIDS, TB, } \\
P . \text { jirovecii } \\
\text { pneumonia }\end{array}$ & No & Johannesburg & $\begin{array}{l}\text { On antiretrovirals, } \\
\text { TB and } P \text {. jirovecii } \\
\text { treatment }\end{array}$ \\
\hline 3 & $73, \mathrm{~F}$ & Urine & $\begin{array}{l}17 \text { November } \\
2015 \text { (ward) }\end{array}$ & $\begin{array}{l}21 \text { November } \\
2015\end{array}$ & 4 & UTI & No & Johannesburg & $\begin{array}{l}\text { Admitted for hip } \\
\text { replacement }\end{array}$ \\
\hline $4^{*}$ & $48, \mathrm{~F}$ & Pus & Outpatient & 23 March 2014 & 4 & Perianal abscess & No & Johannesburg & No prior antibiotics \\
\hline $5^{*}$ & $60, \mathrm{~F}$ & Urine & Outpatient & 7 October 2014 & 8 & UTI & No & Johannesburg & No prior antibiotics \\
\hline $6^{*}$ & $63, \mathrm{~F}$ & Urine & Outpatient & 11 May 2015 & 8 & UTI & No & Johannesburg & $\begin{array}{l}\text { Chronic UTIs. } \\
\text { Previously treated } \\
\text { with nitrofurantoin } \\
\text { and fosfomycin }\end{array}$ \\
\hline $7^{\star}$ & $68, \mathrm{~F}$ & Urine & 28 May 2015 & 28 May 2015 & 4 & UTI & No & Johannesburg & $\begin{array}{l}\text { Admitted for hip } \\
\text { replacement, diabetic }\end{array}$ \\
\hline $8^{*}$ & $36, \mathrm{~F}$ & Urine & Outpatient & 29 May 2015 & 4 & UTI & No & Pretoria & $\begin{array}{l}\text { Previous hospitalisation } \\
\text { (>6 months) for renal } \\
\text { transplant }\end{array}$ \\
\hline $9^{*}$ & $19, \mathrm{~F}$ & Urine & Outpatient & 24 January 2016 & 4 & UTI & No & Cape Town & No prior antibiotics \\
\hline
\end{tabular}

\section{Implications for public health}

The national and global significance of the sudden spread of MCR-1 and the attendant loss of colistin has profound public health implications, and confirms the continuum between colistin use in feed animals and colistin resistance in slaughtered animals, food for human consumption, colonised humans and infected patients. We join the international community in calling for tighter control of colistin use in animal health, including a ban on use for animal growth promotion and the need for an urgent review of its use in metaphylaxis in feed animals and directed therapy in companion animals. We also call for increased restriction of colistin use in patients. In this regard, redefined considerations for empirical and directed use of colistin are urgently warranted. Strict antibiotic stewardship is essential, including a mandatory loading dose of 12 million units, and use only in combination with at least one other agent.
1. The Center for Disease Dynamics, Economics and Policy. The State of the World's Antibiotics, 2015. Washington DC: The Centre for Disease Dynamics, Economics and Policy, 2015. http:// cddep.org/publications/state_worlds_antibiotics_2015\#sthash.S3a3ME0o.dpbs (accessed 19 cddep.org/publicat

2. Brink AJ, Coetzee J, Corcoran C, et al. Emergence of OXA-48 and OXA-181 carbapenemases among Enterobacteriaceae in South Africa and evidence of in vivo selection of colistin resistance as a among Enterobacteriaceae in South Africa and evidence of in vivo selection of colistin resistance as a
consequence of selective decontamination of the gastrointestinal tract. J Clin Micro 2013;51(1):369-

3. Mendelson M, Matsoso MB. A global call for action to combat antimicrobial resistance: Can we get it right this time? S Afr Med J 2014;104(7):478-479. DOI:10.7196/SAMJ.8534

4. Jayol A, Nordmann P, Brink AJ, et al. Heteroresistance to colistin in Klebsiella pneumoniae associated with alterations in the PhoPQ regulatory system. Antimicrob Agents Chemother 2015;59(5):27802784. DOI:10.1128/AAC.05055-14

5. Liu Y-Y, Wang T, Walsh TR, et al. Emergence of plasmid-mediated colistin resistance mechanism MCR-1 in animals and human beings in China: A microbiological and molecular biological study. Lancet Infect Dis 2016;16(2):161-168. DOI:10.1016/S1473-3099(15)00424-7

6. Arcilla MS, van Hattem JM, Matamoros S, et al. Dissemination of the $m c r-1$ colistin resistance gene. Lancet Infect Dis 2016;16(2):147-149. DOI:10.1016/S1473-3099(15)00541-1

7. Poirel L, Kieffer N, Liassine N, et al. Plasmid-mediated carbapenem and colistin resistance in a clinical Poirel L, Kieffer N, Liassine N, et al. Plasmid-mediated car
isolate of Escherichia coli. Lancet Infect Dis 2016, in press.

8. Gerber D. Colistin resistance in E. coli in broiler operations in South Africa. In: V-Tech Report, 11 January 2016. Johannesburg: V-Tech Pty (Ltd), 2016.

Accepted 24 February 2016. 